\title{
APPLICATION OF MICROWAVE(MW)-FIXED TISSUE SAMPLES TO IN SITU HYBRIDIZATION: DETECTION OF CARCINOEMBRYONIC ANTIGEN (CEA) MRNA AND ONCOGENE TRANSGRIPTS IN MW-FIXED COLORECTAL CARCINOMAS USING SULFONATED PROBES
}

\author{
Masahiro MUROTANi, Hideki MORIMOTO, TAKushi MONDEN, \\ Masahiko HIGASHIYAMA, YasuHito KAWASAKI, \\ TAKASHI SHIMANO AND TAKESADA MORI
}

The Second Department of Surgery, Osaka University Medical School, 1-1-50 Fukushima, Fukushima-ku, Osaka 553

\begin{abstract}
Microwave (MW) energy has been reported to permit rapid fixation and good conservation of tissue antigens as well as of tissue morphology. In this paper, we examined the applicability of MW-fixed tissue specimens to in situ hybridization. The preliminary analysis by Northern blot hybridization revealed that no degradation of mRNA occurred following MW irradiation to tissue samples. To determine the optimal conditions for in situ hybridization of MW-fixed tissue sections, we first investigated the in situ localization of carcinoembryonic antigen (CEA) mRNA in MW-fixed colorectal carcinomas using a sulfonated cDNA probe. The results indicated that pretreatment of sections with $\mathrm{HCl}$ could be omitted and the concentration of proteinase $\mathrm{K}$ for tissue digestion could be reduced in MW-fixed specimens. Thus, these specimens provided stronger CEA mRNA signals when compared with routinely fixed ones. On the basis of this result, we examined oncogene expression in $\mathbf{2 6}$ colorectal cancer specimens fixed by MW irradiation, and successfully detected Ha-ras mRNA in $6(23 \%)$, Ki-ras mRNA in $7(27 \%)$, and cmyc mRNA in $12(46 \%)$ specimens. The results of $i$ situ hybridization for the oncogene mRNAs agreed well with those obtained by the immunohistochemical analysis of oncogene products using the specific antibodies to $\mathrm{p}^{21^{\text {ras }}}$ and $\mathrm{p} 62^{\mathrm{myc}}$. Our observations indicated the usefulness of rapid MW fixation for the preservation of mRNA in tissue preparations. MW-fixed tissue samples are applicable to in situ hybridization as well as to the immunohistochemical analysis of the expression of various genes.
\end{abstract}

In situ hybridization is an indispensable technique for the detection and localization of specific nucleic acid sequences in individual cells (8). This method has been applied to the investigation of the expression of genes for structural proteins $(27,37)$, hormones $(2,15,28)$, enzymes $(31)$, and oncoproteins $(9,21,22)$, and has provided much valuable information in the field of cell biology. For the detection of mRNA, it is essential to fix the target mRNA in situ. Although various chemical fixatives, including formalin, paraformaldehyde, and ethanol have been recommended for processing specimens for in situ hybridization $(29,39)$, such immersion fixatives take several hours to penetrate the tissue blocks. Thus, a considerable amount of mRNA may be digested by endogeneous ribonuclease (RNase) during fixation. To minimize degradation of the target mRNA, it is desirable to accomplish tissue fixation as quickly 
as possible. The microwave (MW) fixation method, which was first described by Mayers in 1970 (23), has been reported to accomplish fixation of tissue samples in a matter of seconds. The superiority of rapid fixation by MW energy with respect to preservation of the morphological details and antigenicity of various substances has been confirmed by both light and electron microscopy $(10,12-14,16-20)$, but there have been no previous reports on the applicability of MW-fixed specimens to in situ hybridization. Accordingly, we used MW-fixed specimens for in situ hybridization experiments in the present study. Suitable conditions for the in situ hybridization of MW-fixed specimens were determined by detecting carcinoembryonic antigen (CEA) gene mRNA in colorectal carcinomas using a sulfonated cDNA probe. Then the expression of several oncogene transcripts in MW-fixed colorectal carcinoma specimens was examined by both in situ hybridization and immunohistochemical techniques.

\section{MATERIALS AND METHODS}

Northern blot analysis of MW-fixed specimens

The fresh liver extracted from a sacrificed mouse was divided into two pieces of equal weights and prepared in two manners; one piece was immediately frozen in liquid nitrogen and the other was frozen after MW fixation performed as mentioned below. The total RNA content was isolated from the fresh and MW-fixed tissues by extraction in guanidium isothiocyanate followed by centrifugation through cesium chloride, as described by Chirgwin et al (4). The poly-A(+) RNA was purified from the total RNA by repeated passages through an oligo (dT) cellulose column (type 7, Pharmacia Co., Sweden). An aliquot $(5 \mu \mathrm{g})$ of mRNA was subjected to electrophoresis on $1 \%$ agarose $/ 2.2 \mathrm{M}$ formaldehyde gel and transferred to a nylon filter (Gene Screen Plus, NEN, USA). After hybridization with a ${ }^{32} \mathrm{P}$ labeled probe for mouse $\beta$-actin, the filter was exposed to X-ray film (Kodak, XA-5) overnight at $-70^{\circ} \mathrm{C}$.

Tissue preparation

Cancer tissue specimens were obtained from 26 colorectal cancer patients undergoing surgery. Specimens were cut into pieces of $1 \mathrm{~cm}^{3}$ or smaller and immediately fixed by MW irradiation according to the method described by Login et al. (18-20) with slight modifications. Each specimen was put into a Pyrex glass vial containing $5 \mathrm{ml}$ of diluted aldehyde solution (2\% formaldehyde, $0.05 \%$ glutaraldehyde, $0.05 \mathrm{M}$ phosphate buffered saline, and $0.025 \%$ calcium chloride, $\mathrm{pH} 7.35$ ), and irradiated with MW energy at $500 \mathrm{~W}$ and $2,450 \mathrm{MHz}$ for about $20 \mathrm{sec}$ using a conventional MW oven (National, Model NE-M335). About $500 \mathrm{ml}$ of water in a glass beaker was placed in one corner of the oven to maintain the temperature of the fixation solution within the range of $40 \pm 5^{\circ} \mathrm{C}$ (Fig. 1). After irradiation, specimens were briefly washed in distilled water, dehydrated in graded ethanol at $4^{\circ} \mathrm{C}$, and embedded in paraffin. The adjacent tissue specimen was fixed in $10 \%$ buffered formalin at $4^{\circ} \mathrm{C}$ for several hours and embedded in paraffin. Four-micron sections were cut, placed onto glass slides coated with $0.02 \%$ poly-L-lysine (Sigma Chemical Co., St. Louis, Missouri), baked at $40^{\circ} \mathrm{C}$ for $4 \mathrm{hr}$, dewaxed in xylene, washed in absolute ethanol, and stored at $-70^{\circ} \mathrm{C}$ until use.

Preparation and sulfonation of DNA probe

A plasmid containing CEA cDNA (pCEA55-2) (30) was kindly provided by Dr. 


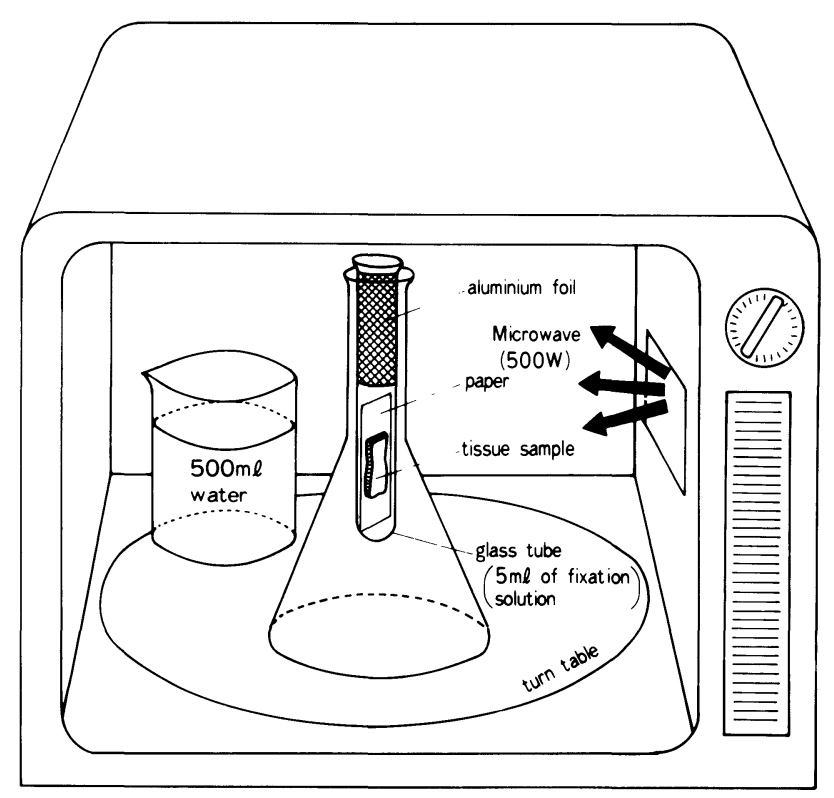

FIG. 1. A diagram of the method of microwave irradiation. A fresh specimen is placed into a pyrex tube containing fixative solution and immediately irradiated for $20 \mathrm{sec}$ at 500 watts.

Oikawa from the Suntory Institute for Biomedical Research. The $380 \mathrm{bp}$ cDNA encoding a portion of the N-domain and domain I of CEA was released from the clone by PvuII digestion, and purified by $2 \%$ agarose gel electrophoresis.

For detection of oncogene mRNAs, an $880 \mathrm{bp}$ HindIII fragment of Ha-MSV ( $\mathrm{v}$ Ha-ras) (6), a 390 bp SacII-XbaI fragment of Ki-MSV (v-Ki-ras) (40), and a 990 bp SalI-PstI fragment of MC29 (v-myc) (1) (Takara Shuzo, Japan) were used as the probes. As a negative control, a 585 bp Sau3AI fragment of pUC19 was prepared.

Sulfonation of the probe was carried out according to the method described elsewhere (3). After denaturation, the DNA probe was incubated in a mixture of sodium metabisulfite and o-methylhydroxylamine at room temperature for $24 \mathrm{hr}$ to incorporate the sulfone group into the cytidine residue of the probe.

In situ hybridization

The in situ hybridization technique for formalin-fixed specimens has been described previously (24-26). In brief, sections were rehydrated, treated with $0.2 \mathrm{~N} \mathrm{HCl}$, heated to $65^{\circ} \mathrm{C}$ in $2 \times \mathrm{SSC}(1 \times \mathrm{SSC}=0.15 \mathrm{M} \mathrm{NaCl}$ and $0.015 \mathrm{M}$ sodium citrate), digested with $5 \mu \mathrm{g} / \mathrm{ml}$ of proteinase $\mathrm{K}$ (Boehringer, Mannheim, West Germany) for $15 \mathrm{~min}$, and then acetylated. For MW-fixed specimens, the pretreatment with $\mathrm{HCl}$ and proteinase $\mathrm{K}$ was modified. Treatment time with $\mathrm{HCl}$ was varied between 0,5 , 10 , and $20 \mathrm{~min}$, while proteinase $\mathrm{K}$ digestion was carried out at the concentrations of $0,2.5$, and $5 \mu \mathrm{g} / \mathrm{ml}$ at $37^{\circ} \mathrm{C}$ for 5 or $15 \mathrm{~min}$. After prehybridization for $4 \mathrm{hr}$, hybridization was carried out in a dry chamber at $42^{\circ} \mathrm{C}$ for 12 to $18 \mathrm{hr}$ using the sulfonated DNA probes. After extensive washing in $2 \times \mathrm{SSC}$ at $42^{\circ} \mathrm{C}$ for several hr, specific hybridization signals were visualized immunohistochemically by the avidin- 


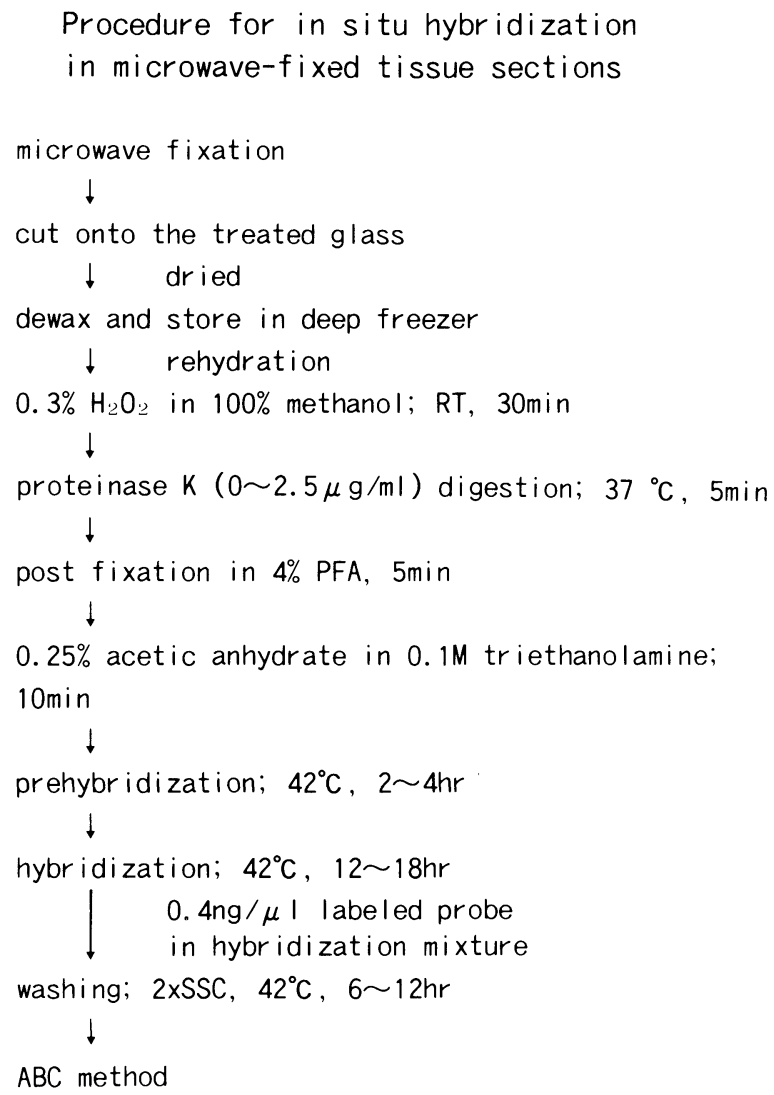

Fig. 2. Procedure for in situ hybridization of microwave-fixed tissue sections. Pretreatment with $\mathrm{HCl}$ could be omitted, and proteinase $\mathrm{K}$ digestion could be reduced compared to the procedure used for formalin-fixed sections.

biotin peroxidase complex ( $\mathrm{ABC}$ ) method using a monoclonal antibody specific to sulfonated DNA (Fig. 2).

Immunohistochemical detection of oncogene products

The adjacent section to that which was subjected to in situ hybridization was used for the immunohistochemical detection of oncogene products. After blocking endogeneous peroxidase, the section was stained by the $\mathrm{ABC}$ method using the monoclonal mouse anti-p2 $1^{\text {ras }}$ antibody, RAP-5 $(12,37)(1: 2,000$, supplied by Dr. J. Schlom, National Cancer Institute, Bethesda, Maryland), and the polyclonal rabbit anti-p62 ${ }^{\text {myc }}$ antiserum R5452 (35) (1:2,000, supplied by Dr. N. Yanaihara, Shizuoka College of Pharmacology, Shizuoka, Japan) respectively as the primary antibodies.

\section{RESULTS}

1. Northern blot hybridization

Approximately identical amounts of total RNA were extracted from the fresh and 
MW-fixed mouse liver samples. By Northern blot hybridization analysis, $\beta$-actin gene expression was detected in both fresh and MW-fixed samples, and there was no evidence of disintegration of the $\beta$-actin mRNA in MW-fixed samples (Fig. 3).

2. In situ hybridization

CEA mRNA was detected in MW-fixed specimens by in situ hybridization using the sulfonated cDNA probe for CEA (Fig. 4a). No improvement in detection was noted following the treatment of sections with $\mathrm{HCl}$, and heat treatment up to $65^{\circ} \mathrm{C}$ in $2 \times \mathrm{SSC}$ did not increase hybridization signals in $\mathrm{MW}$-fixed sections. Proteinase $\mathrm{K}$ digestion $(5 \mu \mathrm{g} / \mathrm{ml})$ for $15 \mathrm{~min}$, which was usually appropriate for formalin-fixed specimens, diminished specific signals and caused the loss of morphological details in MW-fixed tissue sections (Fig. 5). Proteinase K digestion at a concentration of $2.5 \mu$ $\mathrm{g} / \mathrm{ml}$ or less for $5 \mathrm{~min}$ was found to be appropriate for in situ hybridization of MW-fixed samples.

When in situ hybridization was carried out under the optimal conditions, CEA mRNA was clearly localized to the cytoplasm of normal epithelial cells as wel as

\section{Northern blot hybridization (mouse liver)}

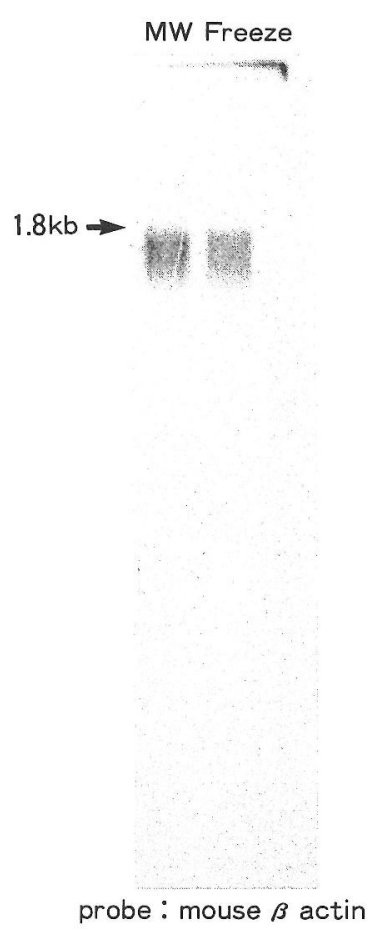

FIG. 3. Northern blot hybridization of $\beta$-actin mRNA from mouse liver samples frozen immediately (right) and after microwave irradiation (left). The $\beta$-actin gene expression was not reduced after microwave irradiation. 


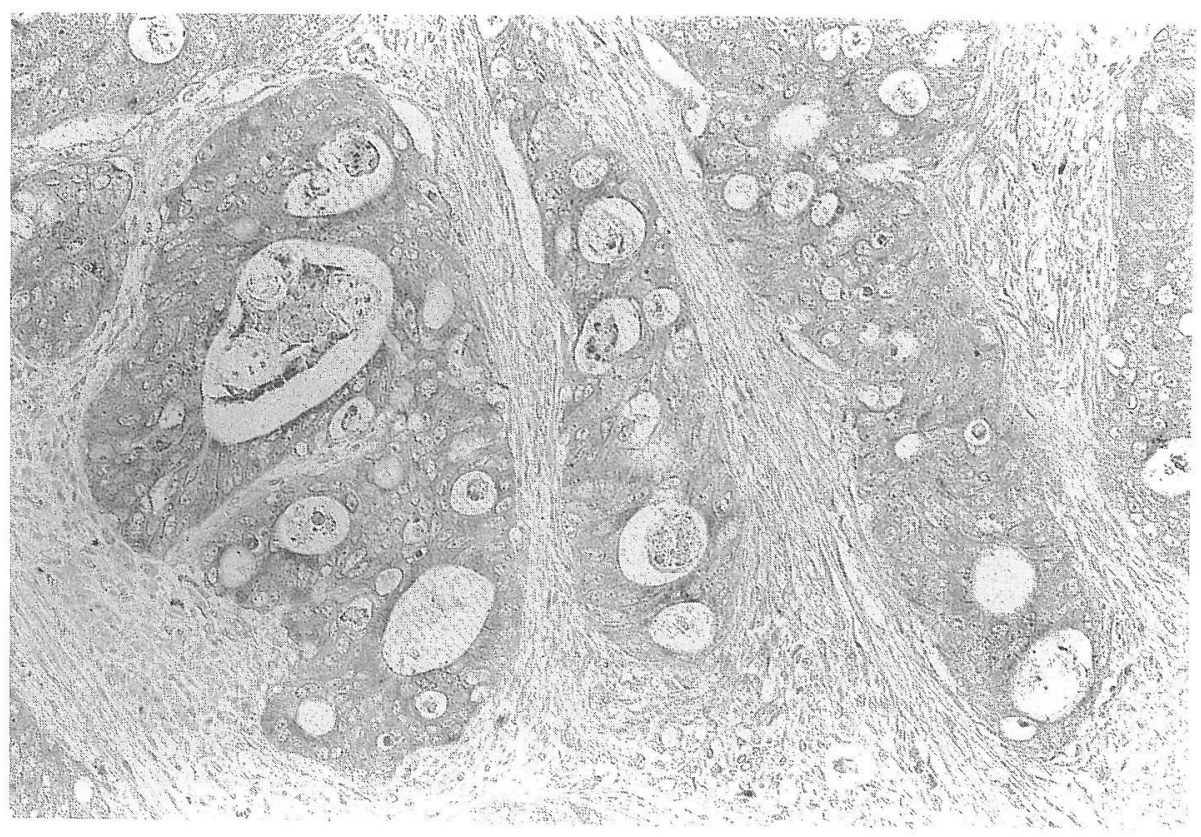

FIG. 4a.

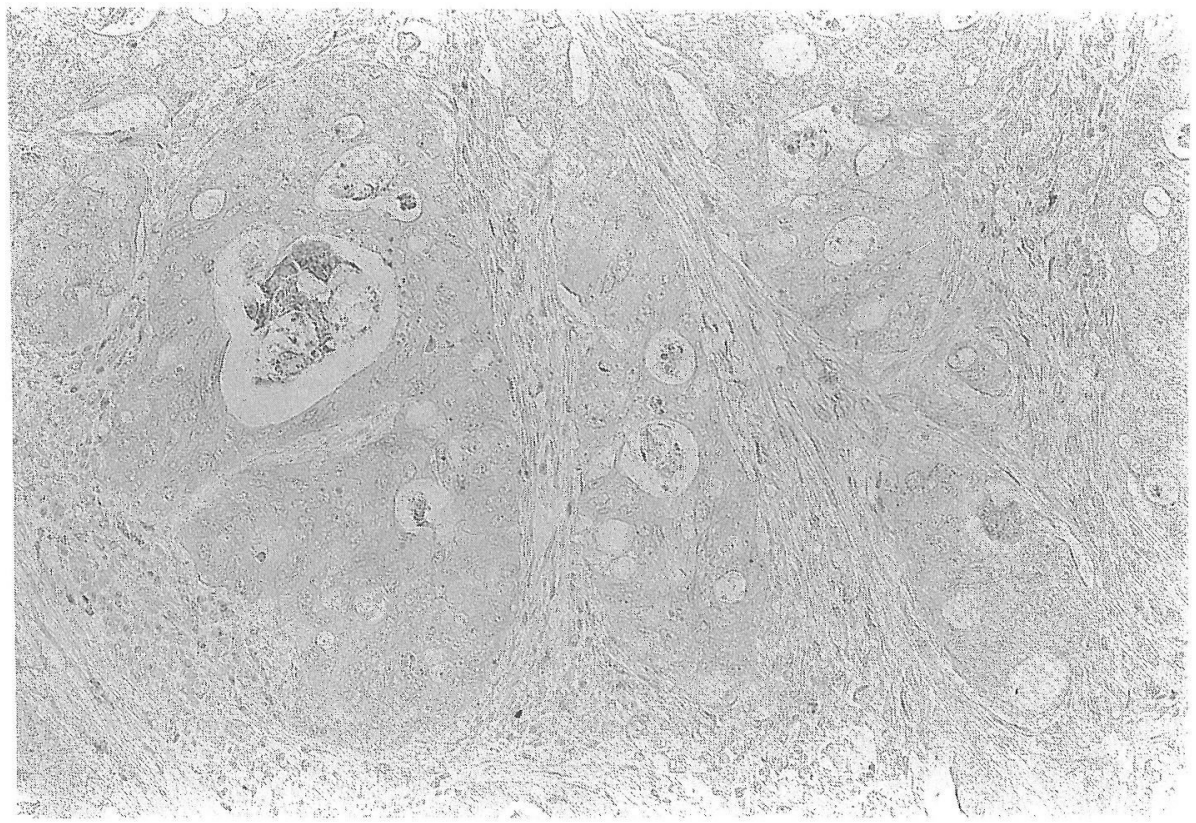

Fig. 4b. 


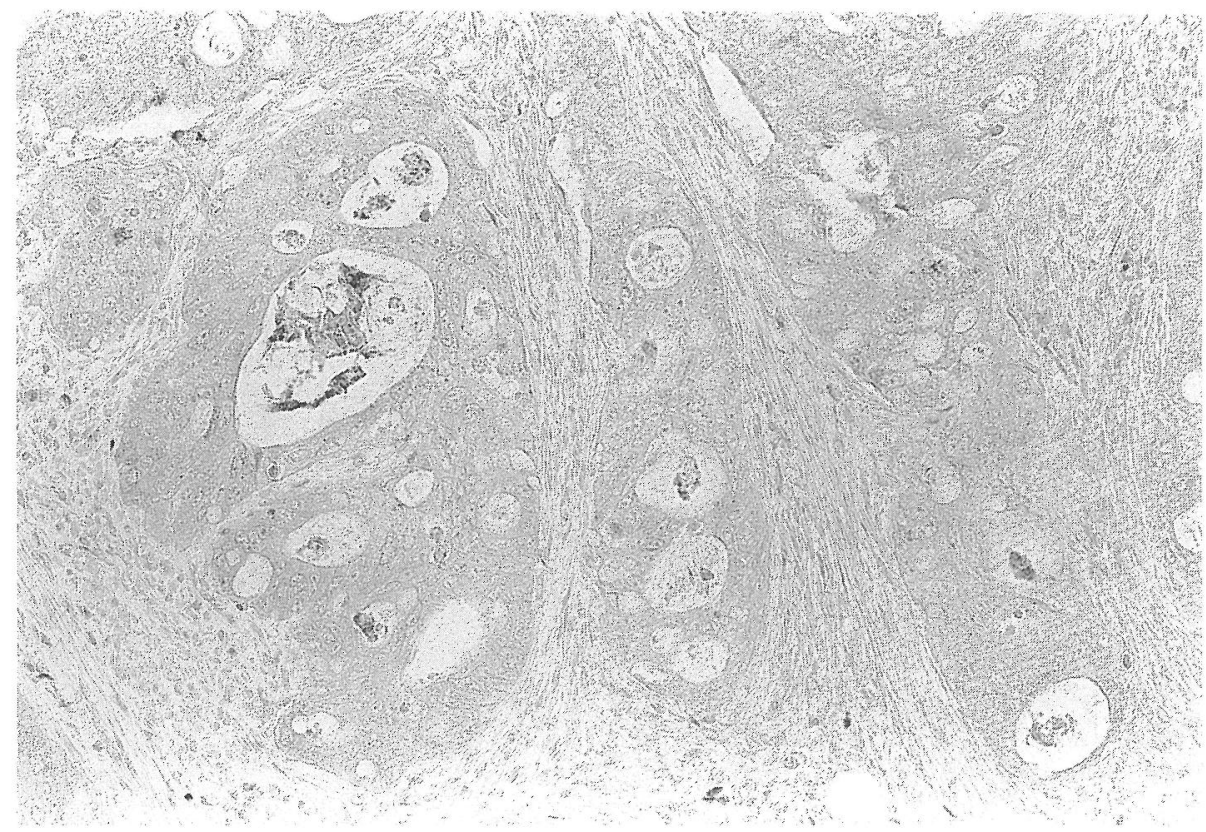

FIG. 4c.

FIgs. 4a-c. Microwave-fixed paraffin sections of colonic carcinoma hybridized in situ with a sulfonated carcinoembryonic antigen cDNA probe (a). Diffuse cytoplasmic staining of cancer cells is observed. The staining is abolished in the adjacent section treated with RNase before hybridization (b), and no hybridization signals are obtained using a nonspecific pUC probe (c).

cancer cells (Fig 6). Treatment of the sections with $0.1 \mathrm{mg} / \mathrm{ml}$ of RNase (bovine pancreatic RNase, Boehringer) in $\mathrm{PBS}$ at $37^{\circ} \mathrm{C}$ for two hr completely abolished these cytoplasmic signals, and no signals were detected by in situ hybridization using a nonspecific vector probe instead of CEA cDNA (Figs. 4b, c).

In situ hybridization using the sulfonated cDNA probes for various oncogenes was performed under the optimal conditions determined by the above experiment. Specific hybridization signals for $\mathrm{Ha}$-ras, $\mathrm{Ki}$-ras, and c-myc were respectively detected in 6,7 , and 12 cases of the 26 colorectal cancer specimens. In most cases, a large proportion of the cancer cells showed diffuse cytoplasmic staining (Fig. 7), but sometimes the heterogeneous staining of a single section was observed (Fig. 8). Immunohistochemically, ras and myc oncogene products were detected in 6 and 17 cases respectively. The immunohistochemical findings generally correlated with the in situ hybridization results (Table 1 ).

\section{DISCUSSION}

In the present study, we examined the applicability of MW fixation to in situ hybridization. A preliminary study of Northern blot hybridization using a mouse $\beta$ actin probe showed that there was no significant degradation of the mRNA in MW-irradiated specimens. Examination with acridine orange staining showed that the 


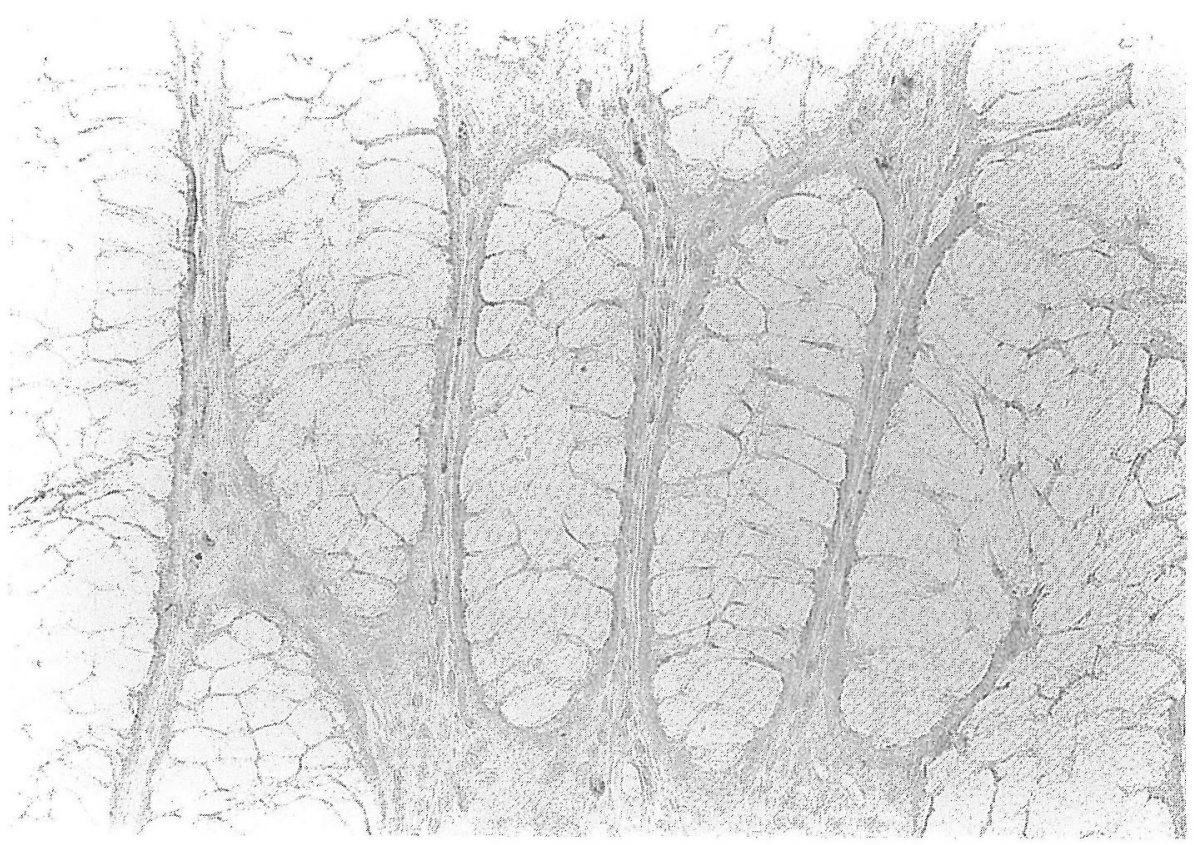

FIG. 5. Expression of carcinoembryonic antigen mRNA in formalin-fixed paraffin section of normal colonic mucosa. No hybridization signals are observed and the morphological details are lost.

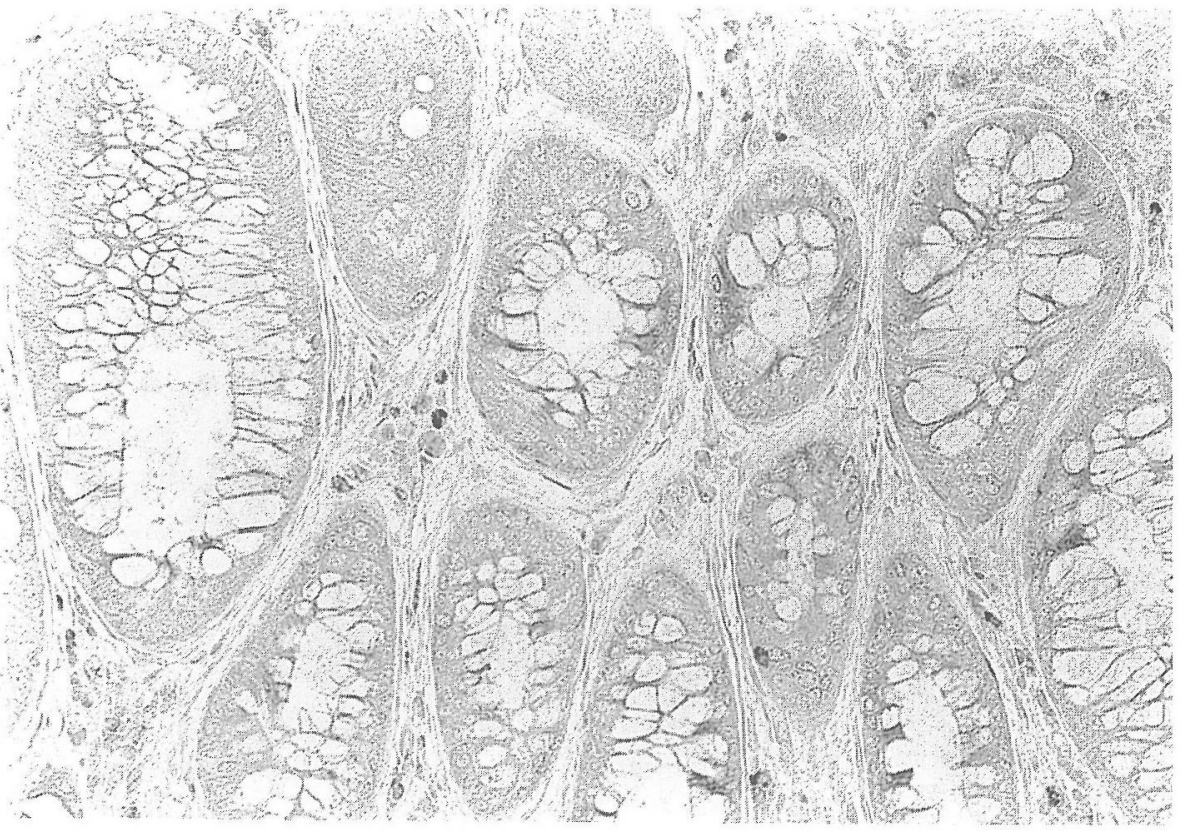

FIg. 6. In situ localization of carcinoembryonic antigen mRNA in normal colonic mucosa. The staining is slightly weaker compared to that of cancer cells. 


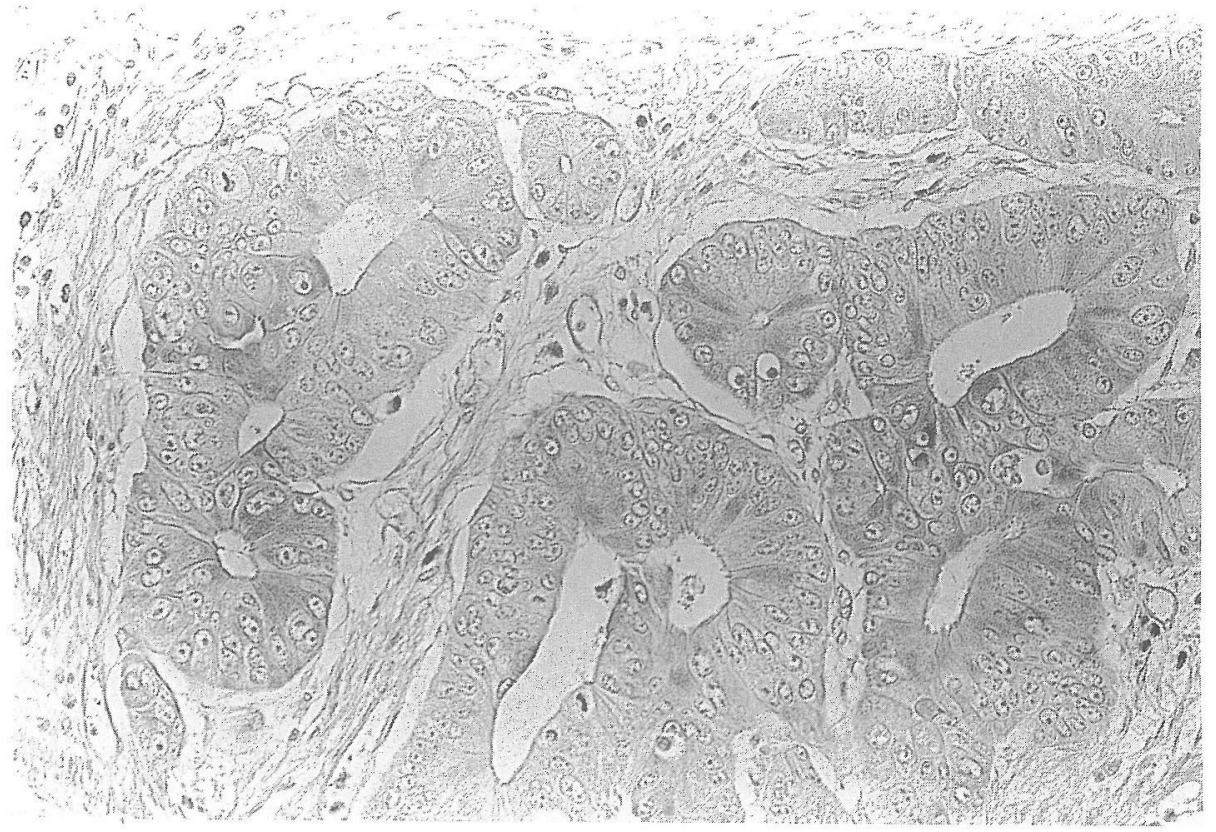

FIG. 7a.

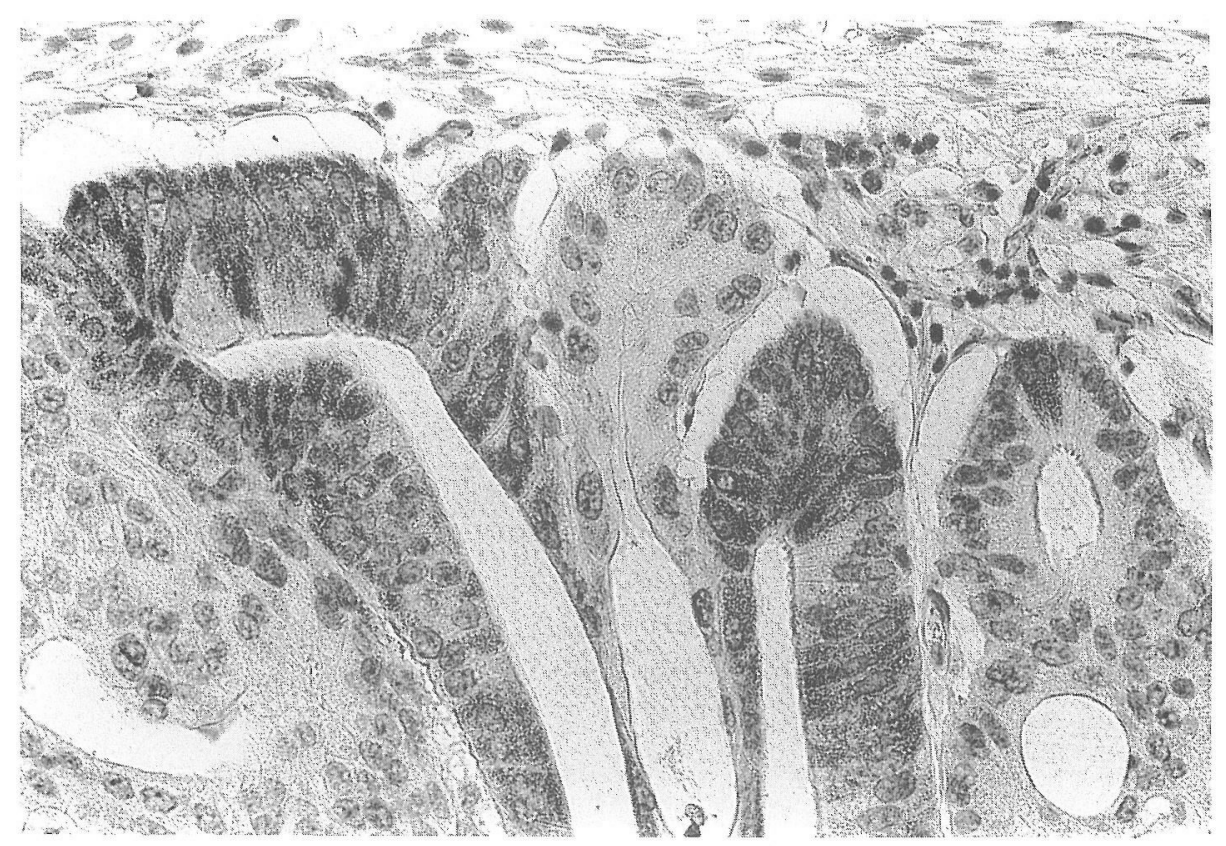

FIGS. 7b. 


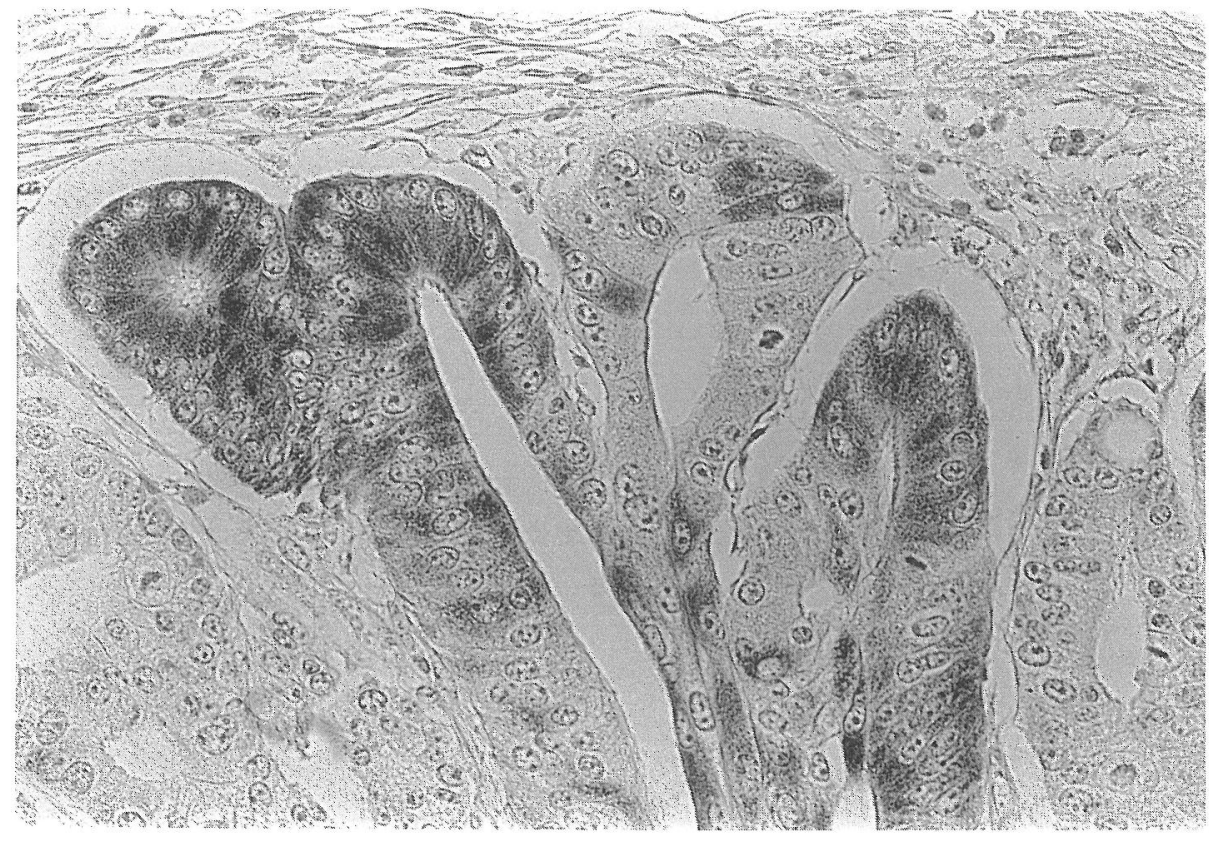

FIG. $7 \mathrm{c}$.

FIGs. 7a-c. In situ detection of Ha-ras (a) and Ki-ras (b) mRNAs and immunohistochemical detection of ras oncogene products (c) in a colonic carcinoma specimen fixed by microwave irradiation. Specific hybridization signals and their corresponding gene products are seen in the cytoplasm of the cancer cells.

preservation of RNA in MW-fixed specimens was superior to that in formalin-fixed ones (data not shown). These findings suggested that MW energy did not alter the covalent bonds in the nucleic acid sequence of mRNA, and caused no significant cross-linking between nucleic acids and proteins. Although deproteination of tissue sections with $0.2 \mathrm{~N} \mathrm{HCl}$ and enzymes such as proteinase $\mathrm{K}$ (at a concentration of $5 \mu \mathrm{g} /$ $\mathrm{ml}$ or more for $15 \mathrm{~min}$ ) prior to hybridization is indispensable for formalin-fixed specimens, we found that $\mathrm{HCl}$ pretreatment could be omitted and the proteinase $\mathrm{K}$ digestion time could be significantly reduced when using $\mathrm{MW}$-fixed specimens. In the detection of CEA mRNA in MW-fixed specimens, optimal hybridization signals were obtained with no $\mathrm{HCl}$ pretreatment and digestion with proteinase $\mathrm{K}$ at a concentration of $2.5 \mu \mathrm{g} / \mathrm{ml}$ for only $5 \mathrm{~min}$. Such simplification of the pretreatment of tissue sections is a great advantage in the preservation of both morphological details and the target mRNA, and we could clearly demonstrate CEA mRNA in normal colonic epithelial cells in which CEA gene transcription is known to occur to a lesser extent than in cancer cells $(5,32)$. Thus, the use of MW-fixed specimens appears to allow the in situ detection of various types of gene transcripts with a high level of sensitivity. We then used MW-fixed specimens to investigate the localization of several oncogene transcripts (Ha-ras, Ki-ras and c-myc), which have been reported to show increased expression in colorectal carcinomas by Northern blotting and/or immunohistochemical analysis $(7,33,34,36,41)$. The results obtained by the in situ 


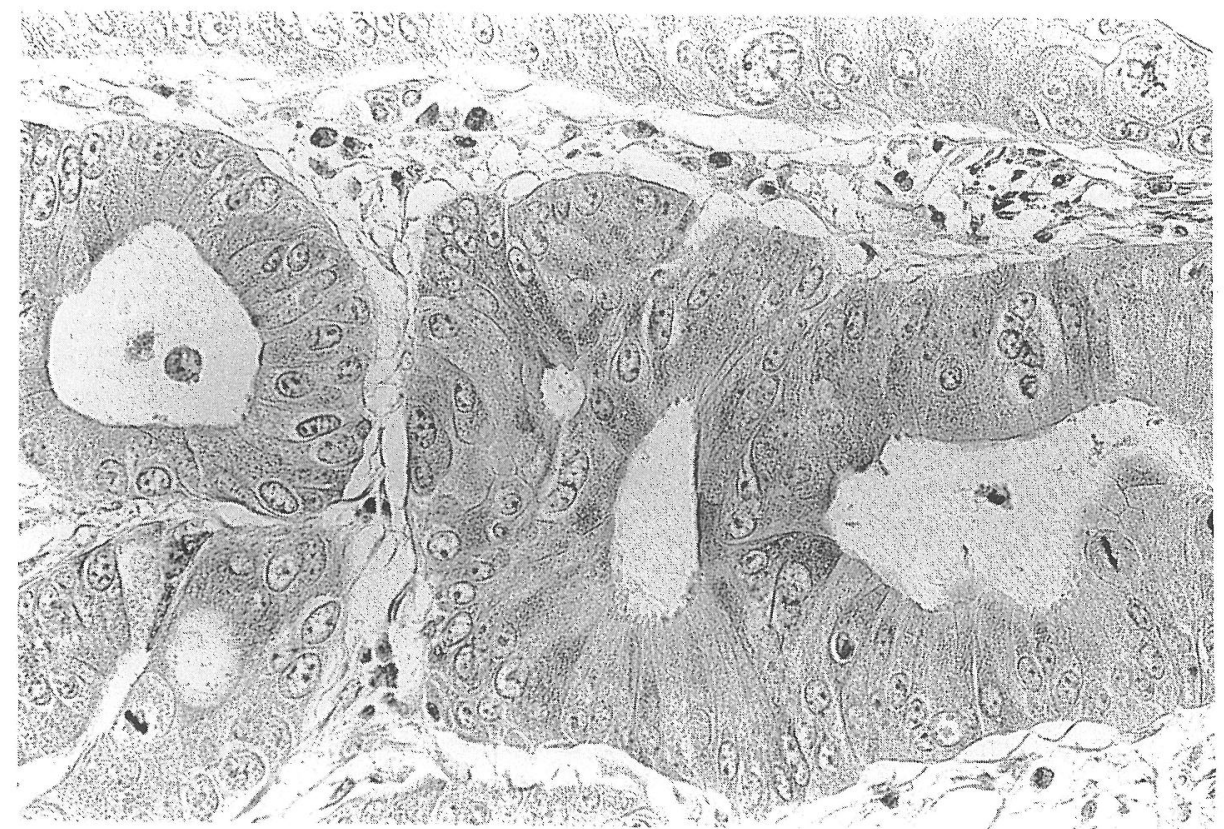

FIG. $8 a$.

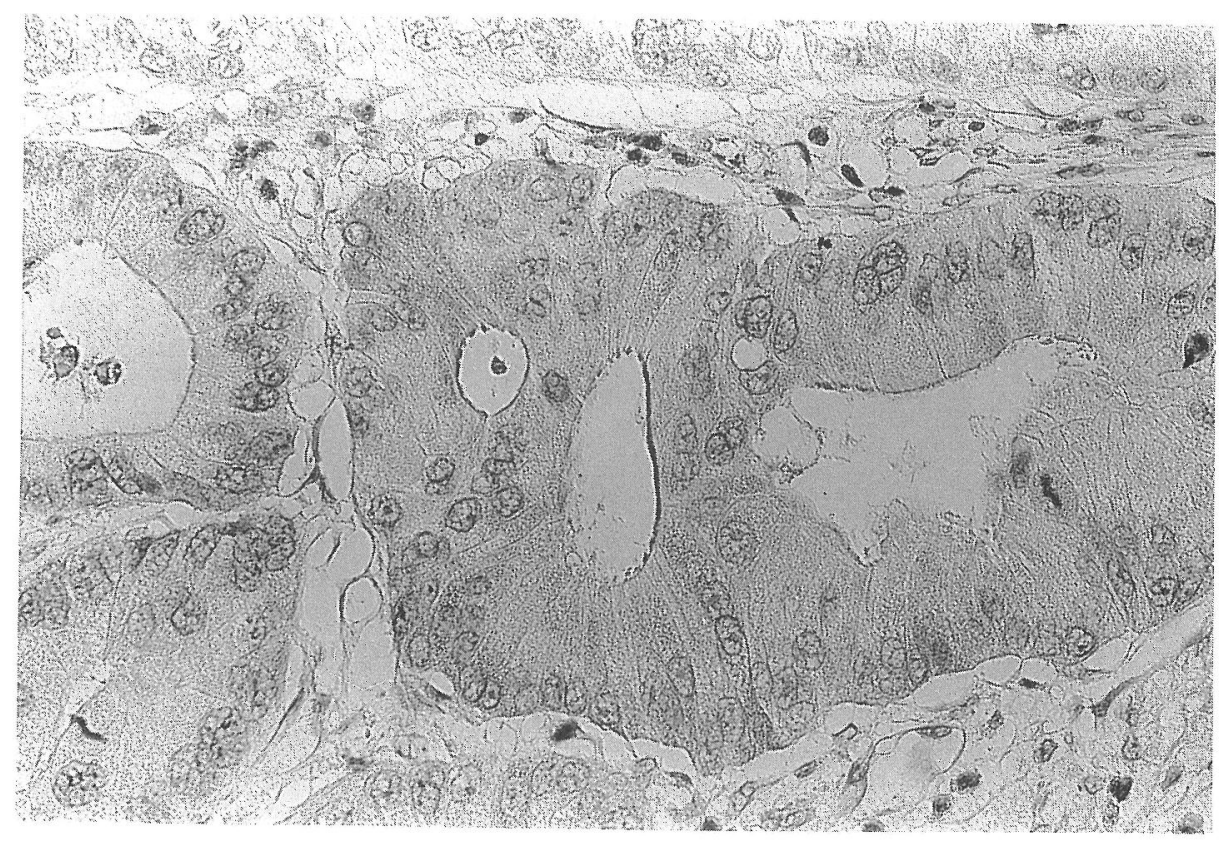

Figs. 8b.

FIGs. 8a, b. In situ detection of c-myc (a) and immunohistochemical detection of myc oncogene products (b) in a colonic carcinoma specimen fixed by microwave irradiation. Heterogeneity of staining is observed for in situ hybridization, while cancer cells are diffusely positive by immunohistochemical detection. 
TABLE 1. Oncogene expression in 26 colorectal carcinoma specimens fixed by microwave irradiation. The results of in situ hybridization for oncogene $m R N A$ s agreed in most cases with those for the immunohistochemical detection of each oncogene product.

Oncogene expression in colorectal carcinomas

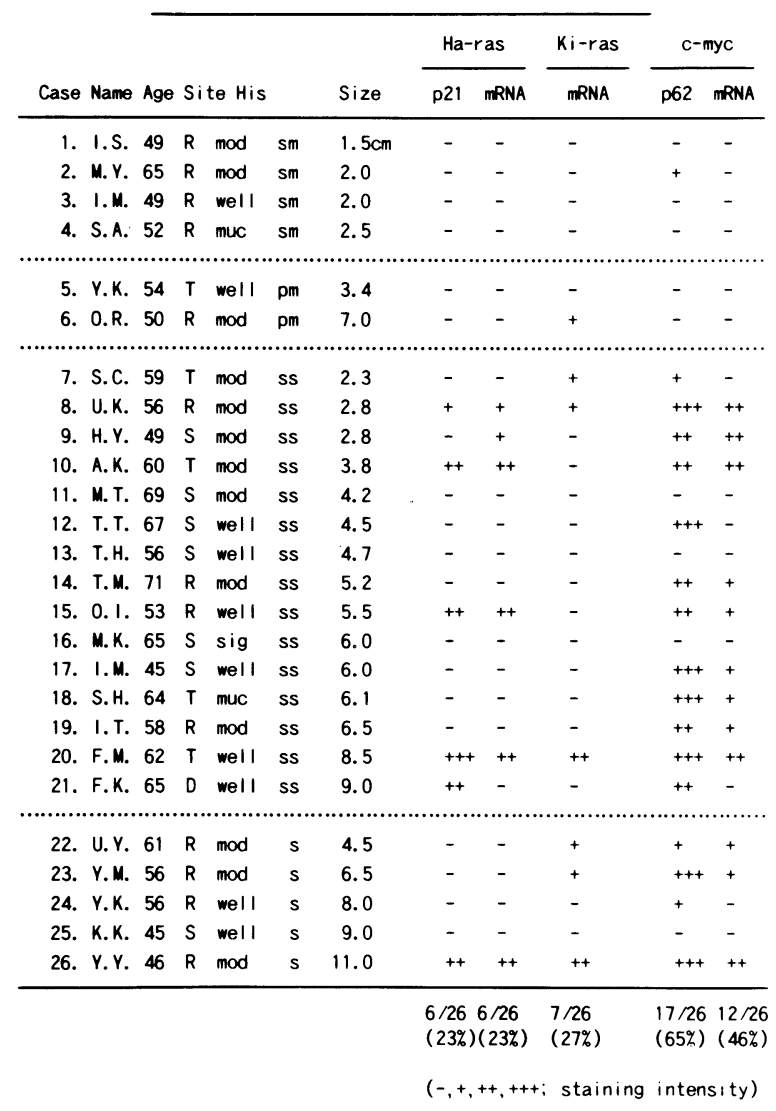

hybridization of these oncogene mRNAs agreed well in most cases with those from immunohistochemical studies performed on the adjacent sections using specific antibodies to each oncogene product. However, cancer cells positive for the oncogene products sometimes lacked hybridization signals for the corresponding mRNA (Fig. 8). The reason for this discrepancy is obscure, but it may be due to several problems which remain to be settled regarding the technique of tissue preparation by MW irradiation. For example, MW irradiation occasionally causes uneven fixation of specimens depending on their size or shape, and the degree of fixation often differs with irradiation time. Furthermore, although MW energy can fix mRNA in situ without any degradation or cross-linking, we found that degradation of RNA in tissue blocks gradually proceeds over the long-term such as periods of 6 months or more (data not shown).

In conclusion, our results indicate the usefulness of MW fixation for the preservation of mRNA in tissue specimens, and MW-fixed tissue sections are applicable to in situ hybridization as well as immunohistochemical analysis. The development of 
special apparatus and further improvements in the technique of MW fixation are expected to allow it to provide much valuable information in the field of biology.

\section{ACKNOWLEDGEMENT}

This work was supported by Grants-in-Aid for Cancer Research and Scientific Research from the Ministry of Education, Science and Culture of Japan.

\section{REFERENCES}

1. Alitalo, K., Bishop, J. M., Smith, D. H., Chen, E. Y., Colly, W. W. and Levinson, A. S.: Nucleotide sequence of the v-myc oncogene of avian retrovirus MC29. Proc. Natl. Acad. Sci. USA 80; 100-104, 1983.

2. Bruneval, P., Fournier, J., Soubrier, F., Belair, M., Silva, J., Guettier, C., Pinet, F., Tardivel, I., Corvol, P., Bariety, J. and Camilleri, J.: Detection and localization of renin messenger RNA in human pathologic tissues using in situ hybridization. Am. J. Pathol. 131; 320-330, 1988.

3. Budowsky, E. I., Sverdlov, E. D. and Monastyrskaya, G. S.: New method of selective and rapid modification of the cytidine residues. FEBS Lett. 25; 201-204, 1985.

4. Chirgwin, J. M., Przybyla, A. E., MacDonald, R. J. and Ruffer, W. J.: Isolation of biologically active ribonucleic acid from sources enriched in ribonuclease. Biochemistry. 18; 5294-5299, 1979.

5. Cournoyer, D., Boucher, D., Benchimol, S., Fuks, A. and Stanner, C. P.: Transcription of genes of the carcinoembryonic antigen family in malignant and nonmalignant human tissues. Cancer Res. 48; 3153-3157, 1988.

6. Ellis, R. W., DeFeo, D., Maryak, J. M., Young, H. A., Shih, T. Y., Chang, E. H., Lowry, D. R. and Scolnick, E. M.: Dual evolutionary origin for the rat genetic sequences of Harvey murine sarcoma virus. J. Virology 36; 408-420, 1980.

7. Evan, G. I., Lewis, G. K., Ramsay, G. and Bishop, J. M.: Isolation of monoclonal antibodies specific for human c-myc proto-oncogene product. Mol. Cell. Biol. 5; 3610-3616, 1986.

8. Gall, J. G. and Pardue, M. L.: Formation and detection of RNA-DNA hybrid molecules in cytological preparations. Proc. Natl. Acad. Sci. USA 63; 378-383, 1969.

9. Gu, J., Linnoila, R. I., Seibel, N. L., Gazdar, A. F., Minna, J. D., Brooks, B. J., Hollis, G. F. and Kirsch, I. R.: A study of myc-related gene expression in small cell lung cancer by in situ hybridization. Am. J. Pathol. 132; 13-17, 1988.

10. Hopwood, D., Coghill, G., Ramsay, J., Milne, G. and Kerr, M.: Microwave fixation: its potential for routine techniques, histochemistry, immunocytochemistry and electron microscopy. Histochem. J. 16; 1171-1191, 1984.

11. Horan Hand, P., Thor, A., Wunderlich, D., Muraro, R., Caruso, A. and Schlom, J.: Monoclonal antibodies of predefined specificity detect activated ras gene expression in human mammary and colon carcinomas. Proc. Natl. Acad. Sci. USA 81; 5227-5231, 1984.

12. Kayser, K., Stute, H., Lubcke, J. and Wazinski, U.: Rapid microwave fixation-a comparative morphometric study. Histochem. J. 20;347-352, 1988.

13. Leong, A. S. Y., Daymon, M. E. and Milios, J.: Microwave irradiation as a form of fixation for light and electron microscopy. J. Pathol. 146; 313-321, 1985.

14. Leong, A. S. Y. and Milios, J.: Rapid immunoperoxidase staining of lymphocyte antigens using microwave irradiation. J. Pathol. 148; 183-187, 1986.

15. Loyd, R. V., Cano, M. and Landefeld, T.: The effects of estrogens on tumor growth and on prolactin and growth hormone mRNA expression in rat pituitary tissues. Am. J. Pathol. 133; 397-406, 1988. 
16. Login, G. R. and Dvorak, A. M.: Microwave energy fixation for electron microscopy. $A m$. J. Pathol. 120; 230-243, 1985.

17. Login, G. R., Stavinoha, W. B. and Dvorak, A. M.: Ultrafast microwave energy fixation for electron microscopy. J. Histochem. Cytochem. 34; 381-387, 1987.

18. Login, G. R., Schnitt, S. J. and Dvorak, A. M.: Rapid fixation of human tissues for light microscopic immunoperoxidase identification of diagnostically useful antigens. Lab. Inv. 57; 585-591, 1987.

19. Login, G. R., Galli, S. J., Morgan, E., Arizono, N., Schwartz, L. B. and Dvorak, A. M.: Rapid microwave fixation of rat mast cells. I. Localization of granule chymase with an ultrastructural postembedding immunogold technique. Lab. Inv. 57; 592-599, 1987.

20. Login, G. R. and Dvorak, A. M.: Microwave fixation provides excellent preservation of tissue, cells and antigens for light and electron microscopy. Histochem. J. 20; 373-387, 1988.

21. Mariani-Costantini, R., Escot, C., Theillet, C., Gentile, A., Merlo, G., Lidereau, R. and Callahan, R.: In situ c-myc expression and genomic status of the c-myc locus in infiltrating ductal carcinomas of the breast. Cancer Res. 48; 199-205, 1988.

22. Mariani-Costantini, R., Theillet, G., Hutzell, P., Merlo, G., Schlom, J. and Callahan, R.: In situ detection of c-myc mRNA in adenocarcinomas, adenomas, and mucosa of human colon. J. Histochem. Cytochem. 37; 293-298, 1989.

23. Mayers, C. P.: Histological fixation by microwave heating. J. Clin. Pathol. 23; 273-275, 1970.

24. Monden, T., Morimoto, H., Higashiyama, M., Murotani, M., Tomita, N., Shimano, T., Okuda, H. and Mori, T.: In situ detection of Ha-ras and c-myc mRNA in cancer cell lines and tissue sections of colorectal cancer using sulfonated DNA probes. Acta histochem. cytochem. 21; 201-210, 1988.

25. Monden, T., Murotani, M., Higashiyama, M., Kawasaki, Y., Shimano, T. and Mori, T.: In situ localization of CEA gene transcripts and products. The Carcinoembryonic Antigen Gene Family, ed. by A. Yachi and J. E. Shively, Elsevier Science Publishers BV, Amsterdam, 1989, pp. 111-118.

26. Morimoto, H., Monden, T., Shimano, T., Higashiyama, M., Tomita, N., Murotani, M., Matsuura, N., Okuda, H. and Mori, T.: Use of sulfonated probes for in situ detection of amylse mRNA in formalin-fixed paraffin sections of human pancreas and submaxillary gland. Lab. Inv. 57; 737-741, 1987.

27. Niedobitek, G., Finn, T., Herbst, H. and Stein, H.: Detection of viral genomes in the liver by in situ hybridization using ${ }^{35} \mathrm{~S}$-bromodeoxyuridine and biotin-labeled probes. Am. J. Pathol. 134; 633-639, 1989

28. Nogami, H., Suzuki, K., Enomoto, H. and Ishikawa, H.: Studies on the development of growth hormone and prolactin cells in the rat pituitary gland by in situ hybridization. Cell Tissue Res. 255; 23-28, 1989.

29. Nuovo, G. J. and Richart, R. M.: Buffered formalin is the superior fixative for the detection of HPV DNA by in situ hybridization analysis. Am. J. Pathol. 134; 837-842, 1989.

30. Oikawa, S., Nakazato, H. and Kosaki, G.: Primary structure of carcinoembryonic antigen (CEA) deduced from cDNA sequences. Biochem. Biophys. Res. Commun. 142; 511-518, 1987.

31. Perrot-Rechenmann, C., Joannes, M., Squalli, D. and Lebacq, P.: Detection of phosphoenolpyruvate and ribulose 1, 5-bisphosphate carboxylase transcripts in maize leaves by in situ hybridization with sulfonated cDNA probes. J. Histochem. Cytochem. 37; 423-428, 1989.

32. Sato, C., Miyaki, M., Oikawa, S., Nakazato, H. and Kosaki, G.: Differential expression of carcinoembryonic antigen and nonspecific crossreacting antigen genes in human colon adenocarcinomas and normal colon mucosa. Jpn. J. Cancer. Res. 79; 433-437, 1988.

33. Sikora, K., Chan, S., Evan, G., Gabra, H., Markham, N., Stewart, J. and Watson, J.: c-myc oncogene expression in colorectal cancer. Cancer 59; 1289-1295, 1985.

34. Spandidos, D. A. and Kerr, I. B.: Elevated expression of the human ras oncogene family in premalignant and malignant tumours of the colorectum. Br. J. Cancer 49; 681-688, 1983. 
35. Suzuki, T., Yanaihara, C., Hirota, M., Iwafuchi, M., Inoue, T., Mochizuki, T., Iguchi, K., Abe, K. and Yanaihara, N.: Immunohistochemical demonstration of c-myc gene product in tumors induced in nude mice by human hepatoblastoma: A study with antiserum to a related synthetic peptide. Biomed. Res. 7; 365-367, 1986.

36. Tanaka, T., Slamon, D. J., Battifora, H. and Cline, M. J.: Expression of p21 ras oncoproteins in human cancers. Cancer Res. 46; 1465-1470, 1986.

37. Tase, T. T., Okagaki, T., Clark, B. A., Manias, D. A., Ostrow, R. S., Twiggs, L. B. and Faras, A. J.: Human papillomavirus types and localization in adenocarcinoma and adenosquamous carcinoma of the uterine cervix: A study by in situ DNA hybridization. Cancer Res. 48; 993-998, 1988.

38. Thor, A., Ohuchi, N., Horan Hand, P., Callahan, R., Weeks, M. O., Theillet, C., Lidereau, R., Escot, C., Page, D. L., Vilasi, V. and Schlom, J.: Ras gene alterlations and enhanced levels of ras p21 expression in a spectrum of benign and malignant human mammary tissues. Lab. Inv. 55; 603-615, 1986.

39. Tournier, I., Bernuau, D., Pollard, A., Schoevaert, D. and Feldmann, G.: Detection of albumin m-RNAs in rat liver by in situ hybridization: Usefulness of paraffin embedding and comparison of various fixation procedures. J. Histochem. Cytochem. 35; 453-459, 1987.

40. Tsuchida, N., Ryder, T. and Ohtomo, E.: Nucleotide sequence of the oncogene encoding the p21 transforming protein of Kirsten murine sarcoma virus. Science 217; 937-939, 1982.

41. Williams, A. R. W., Piris J., Spandidos, D. A. and Wyllie, A. H.: Immunohistochemical detection of the ras oncogene 21 product in an experimental tumour and in human colorectal neoplasms. Br. J. Cancer; 687-693, 1985. 